\title{
Bilateral cryptogenic metastases to the femur and foot
}

\author{
Wilson I B Onuigbo ${ }^{*}$ and Chukwuemeka B Eze ${ }^{2}$ \\ ${ }^{1}$ Department of Pathology, The National Orthopaedic Hospital, Enugu 400001, Nigeria \\ ${ }^{2}$ Department of Surgery, The National Orthopaedic Hospital, Enugu 400001, Nigeria
}

\begin{abstract}
Organ selectivity in cancer metastasis has long been puzzling. A historical angle is that this is due to soil suitability. A personal angle is to sift the phenomenon as 12 classes. Of these classes, cryptogenicity symbolizes the blossoming of the metastasis when the primary is hidden. As that of bone is striking, both historical and epidemiological researches were indicated. Therefore, a case report involving a Nigerian woman with two such lower limb deposits was deemed to be worthy of documentation.
\end{abstract}

\section{Introduction}

One of the important phenomena recognized by the medical masters of yester years was that cancer was the seed and the soil was the apt landing site [1,2]. Stephen Paget was erroneously held to be the discoverer of this idea [3]. However, I showed that his father was aware of it $[4]$ and so were other medical masters $[5,6]$.

Coming to present endeavors, I revealed in 1974 that 12 classes were definable [7]. In particular, cryptogenicity was defined as when the primary was hidden while the secondary blossomed [8]. In particular, bone was the star performer [9]. However, I am struck that the hidden source may be bones in separate parts. An example deserves 2-fold documentation.

\section{Investigation}

The background to this report was the proposal by the Birmingham group [10] that the establishment of a histopathology data pool favors epidemiological analysis. In pursuit of this principle, when I became the pioneer pathologist at the Regional pool at Enugu, the opportunity arose repeatedly to discover interesting data hidden in copious materials obtained from the Igbo ethnic group [11]. The series has included such findings as those of the breast, including carcinosarcoma [12], intramammary lymph nodes [13] and the onchocerca nodule [14]. Accordingly, this paper illuminates the occurrence of cryptogenicity in bone not only in the femur but also in the foot.

\section{Case report}

OM, a 65-year-old woman, attended Dr Eze's Clinic at the National Orthopaedic Hospital, Enugu. She complained of pain in the left hip of 8 months duration. She was progressively unable to bear weight. Moreover, there was occasional hematuria. There was also a cystic swelling in the dorsum of the right foot, this being attributed to trauma. $\mathrm{X}$-Ray revealed osteolytic lesion of the neck, of the femur with fracture of that bone. There was also complete osteolysis of the 5th metatarsal bone. Therefore, incisional bone biopsies were carried out. Several pale wedges up to $2 \mathrm{~cm}$ across were received in respect of the femur while smaller fragments were from the foot.

On microscopy, the femur was riddled with epithelial malignancy in which glands were well differentiated. As regards the foot, the appearances were the same. Accordingly, metastatic adenocarcinoma was diagnosed with the following comment: "There is a wide field of choice re primary site." However, follow up was not feasible from the clinical angle unfortunately.

\section{Discussion}

The clue as to site of origin was the fact of "occasional hematuria" to which the patient admitted. Now, this case falls into the weighty subject of metastases of unknown origin [15]. Therefore, a heavy review with 146 references was consulted but it mentioned only a few primary organs namely, lung, kidney, breast, prostate, thyroid, ovary and liver. Thus, the kidney has been one of the suspicious sites.

However, what the kidney is best associated with is not adenocarcinoma per se but the clear cell carcinoma. Thus, it was mentioned classically with respect to the thyroid gland [16].

An odd feature was the laterality of the bone sites. Thus, the femur was attacked on the right side but the foot on the left side. Had the distribution been one-sided, lymphatic spread would have been implicated. Therefore, blood spread has to be considered. Incidentally, Batson championed the occurrence of the vertebral venous system mode of spread [17]. In my view, this is challengeable [18].

\section{References}

1. Moxon W (1871) Osteo-colloid cancer of the skeleton. Trans Path Soc Lond 22: 206.

2. Bell C (1816) Surgical observations. Lond: Longman, pp. 376, 380.

3. Paget S (1889) The distribution of secondary growths in cancer of the breast. Lancet i: 571 .

4. Paget J (1853) Lectures on surgical pathology. Lond: Longman, Brown, Green and Longmans 2: 580.

${ }^{\star}$ Correspondence to: Wilson I B Onuigbo, Department of Pathology, The National Orthopaedic Hospital, Enugu 400001, Nigeria, E-mail: wilson.onuigbo@gmail.com

Key words: cancer, metastasis, selectivity, cryptogenicity, lower limb, Nigeria

Received: June 30, 2018; Accepted: July 11, 2018; Published: July 13, 2018 
5. Cooper S (1832) Some account of a case in which the left femur and the fifth rib on the right side were fractured in consequence of disease, the bladder being at the same time in the state of carcinomatous ulceration, with observations. Med Chir Trans 17: 51-57. [Crossref]

6. Warren JC (1837) Surgical observations on tumours. Boston, Crocker and Brewster $239,258,282$

7. Onuigbo WI (1974) Organ selectivity in human cancer metastasis. A review. Oncology 30: 294-303. [Crossref]

8. Onuigbo WI (1963) A history of the cell theory of cancer metastasis. Gesnerus 20 90-95. [Crossref]

9. Onuigbo WI (1976) Cancerous pathologic fractures. Concepts in nineteenth century. $N$ Y State J Med 76: 771-772. [Crossref]

10. Macartney JC, Rollason TP, Codling BW (1980) Use of a histopathology data pool for epidemiological analysis. J Clin Pathol 33: 351-355. [Crossref]

11. Basden GT (1966) Niger Ibos. Lond: Cass.
12. Onuigbo WIB (2015) Epidemiologic analysis of the surgical specimens of breast carcinosarcomas examined at a reference laboratory in a Nigerian Community. Surg Res 1: 25-27.

13. Onuigbo WIB (2015) Breast biopsy: the harvesting of lymph nodes presenting as lumps in a Nigerian community indicates that preventive cancer education is succeeding. $J$ Cancer Prev Curr Res 3: 00095.

14. Onuigbo WIB (2002) Breast lumps due to nodulation in onchocerciasis. Ebonyi Med $J 1: 37-39$.

15. Haskell CM, Cochran AJ, Barsky SH, Steckel RJ (1988) Metastasis of unknown origin. Curr Probl Cancer 12: 5-58. [Crossref]

16. Madore P, Lan S (1975) Solitary thyroid metastasis from clear-cell renal carcinoma Can Med Assoc J 112: 719, 721. [Crossref]

17. Batson OV (1940) The function of the vertebral veins and their role in the spread of metastases. Ann Surg 112: 138-149. [Crossref]

18. Onuigbo WI (1975) Batson's theory of vertebral venous metastasis: a review. Oncology 32: 145-150. [Crossref]

Copyright: $@ 2018$ Onuigbo WIB. This is an open-access article distributed under the terms of the Creative Commons Attribution License, which permits unrestricted use, distribution, and reproduction in any medium, provided the original author and source are credited. 